\title{
PENGARUH METODE CHAIN WRITING TERHADAP HASIL BELAJAR MENULIS SISWA KELAS 3 SEKOLAH DASAR
}

\author{
Retno Fitriyanti, Eunice Widyanti Setyaningtias \\ Retnokian29@gmail.com, Eunice.widyanti@gmail.com \\ Program studi PGSD-FKIP, Universitas Kristen Satya Wacana

\section{THE EFFECT OF CHAIN WRITING METHOD ON WRITING FOR GRADE 3 STUDENTS}

\begin{abstract}
In Indonesian subject, students are expected to have creativity and skills in putting words into sentences and sentences into succinct and meaningful paragraphs. Based on this thinking, this research was done in Grade 3 in Tumbuh 3 Elementary School, Jogjakarta, semester 1 year 2016/2017 by using chain writing method. Chain writing itself is a method used to assist students in compiling a paragraph based with the help of the images and or previous sentences from friends. The purpose of this research is to know the influence of chain writing method to students' writing result This study was an experimental research, with pretest and posttest for both students who have special and different needs as well as students in general. Provision of treatment to each student is different, considering that this school is a multi-age inclusion school. Different children's condition of each individual requires teachers to work more closely in dealing with all students with team teaching in each class. By using this chain writing method, all students seemed to have an interest in writing, with no exception for students with special needs. Provision of treatment to special needs students makes them more interested in writing activities, although it should be with continuous mentoring from the teachers. The final results obtained a significant positive effect,compared to the result without the chain writing model.
\end{abstract}

Keywords: Chain Writing Method, Bahasa Indonesia, writing.

\section{Article Info}

Received date: 29 April $2017 \quad$ Revised date: 10 Mei 2017

Accepted date: 18 September 2017

\section{PENDAHULUAN}

Bahasa adalah kunci dalam setiap manusia untuk dapat berinteraksi dengan manusia lain di berbagai belahan dunia manapun. Sekolah-sekolah berstandar internasional yang sebagian besar siswanya adalah orang asing murni atau keturunan serta perpaduan antara Indonesia dan negara luar, kini sedang gencar untuk menggalakkan pemakaian bahasa Indonesia dalam kehidupan sehari-hari, meskipun tidak menghilangkan bahasa Inggris sebagai bahasa utama mereka. Menurut UU No.20 Tahun 2003 tentang Sisdiknas pasal 33, ayat (1) bahasa Indonesia sebagai Bahasa Negera menjadi bahasa pengantar dalam pendidikan nasional. Salah satu sekolah yang menerapkan hal tersebut adalah SD Tumbuh 3 Jogjakarta. Sedangkan, pasal 33 ayat (3) UU No.20 Tahun 2003 tentang Sisdiknas menyatakan bahwa bahasa asing dapat digunakan sebagai bahasa pengantar pada satuan pendidikan tertentu untuk mendukung kemampuan berbahasa asing peserta didik.

Sekolah berstandar internasional dan inklusi ini tetap mengajarkan Bahasa Indonesia dan kebudayaan Jawa pada siswa-siswanya. Kemampuan siswa-siswa di sekolah ini sangat beragam sehingga para pengajar harus menggunakan berbagai metode untuk menyampaikan setiap materi yang ada pada siswa-siswa yang ada di Sekolah Tumbuh, hal ini sejalan dengan UU No.20 Tahun 2003 pasal 32 ayat (1) yang menyatakan pendidikan khusus merupakan pendidikan bagi para peserta didik yang memiliki tingkat kesulitan dalam mengikuti proses pembelajaran karena kelainan fisik, emosional, mental, sosial, dan/atau memiliki kecercasan dan bakat istimewa. Kata inklusi digunakan untuk memberikan makna yang lebih tersirat pada istilah anak berkebutuhan khusus, hal ini dimaksudkan supaya setiap anak yang memiliki karakteristik yang berbeda tidak merasa bahwa 
dirinya berbeda akan tetapi sama dengan semua teman-teman yang lain yang tidak memiliki karakteristik yang berbada. Sebagian besar dari siswa-siswa yang belajar di SD Tumbuh 3 memiliki latar belakang yang sama, yaitu keluarga yang membiasakan mereka menggunakan Bahasa Inggris dalam kehidupan sehari-hari. Hal ini membuat para guru menerapkan banyak cara untuk meningkatkan hasil belajar siswa, diantaranya adalah drill chain writing atau menulis berantai ini metode yang membantu dalam mata pelajaran Bahasa Indonesia terutama untuk penyusunan kalimat menjadi sebuah paragraf yang runtut.

Berdasarkan paparan diatas, rumusan masalah yang diambil adalah bagaimana pengaruh metode chain writing terhadap hasil belajar menulis siswa kelas 3 SD Tumbuh 3 Jogjakarta semester I tahun pelajaran 2016/2017. Tujuan yang hendak dicapai dari penelitian ini adalahmengetahui pengaruh metode chain writing terhadap hasil belajar siswa kelas 3 SD Tumbuh 3 Jogjakarta.

\section{KAJIAN PUSTAKA}

Arti Menulis adalah membuat huruf (angka dan sebagainya) dengan pena (pensil, kapur, dsb), anak-anak sedang belajar, melahirkan pikiran atau perasaan (seperti mengarang, membuat surat). Myhill, 2011:6 menyatakan bahwa belajar menulis tidak sesingkat hanya belajar secara general saja, tetapi menulis adalah belajar bagaimana membuat kalimat yang memiliki makna dan berarti. Menulis adalah menurunkan atau melukiskan lambang-lambang grafik yang menggambarkan suatu bahasa yang dipahami seseorang, sehingga orang lain dapat membaca lambang-lambang grafik tersebut jika mereka memahami lambang dan grafis tersebut (Tarigan, 2008:21). Berdasarkan pemaparan para ahli tersebut, dapat disimpulkan bahwa menulis adalah kegiatan mengembangkan pikiran berdasarkan penyusunan kalimat atau paragraf yang memiliki makna yang runtun serta dapat dimengerti oleh khalayak umum serta disampaikan secara tersurat.

Anak berkebutuhan khusus merupakan istilah lain untuk menggantikan kata "Anak Luar Biasa (ALB) yang mempunyai karakteristik yang berbeda antara satu dan lainnya. Termasuk dalam perbedaan karakter adalah anak yang mengalami hendaya (impaiment) penglihatan, anak dengan hendaya pendengaran dan bicara, anak dengan hendaya perkembangan kemampuan, anak dengan hendaya kondisi fisik atau motoric, anak dengan hendaya perilaku maladjustment, anak dengan hendaya autism, anak dengan hendaya hyperactive, anak dengan hendaya belajar dan anak dengan hendaya kelainan perkembangan ganda (Delphie, 2006).

Metode chain writing adalah metode yang digunakan untuk membantu siswa dalam pelajaran bahasa khususnya dalam kegiatan menulis. Meyakinkan anak untuk terus menggambar sebagai bentuk mereka tetap belajar menulis sesuatu secara konvensional daripada memisahkan antara belajar menulis dan menggambar akan membuat anak lebih cepat belajar dan memungkinkan seorang anak akan menghasilkan tulisan yang lebih kompleks dari usia mereka(Mackenzie \& Veresov, 2013).

Penggunaan metode chain writing dalam penelitian ini adalah secara berkelompok. Pada awal pembelajaran peserta didik akan diberikan pancingan berupa gambar dan mereka akan menyusun kalimat menjadi paragraf. Untuk siswa-siswa dengan karakter dan kebutuhan yang berbeda (hyperactive), perlakuan ini juga sama karena mereka mampu untuk menjelajah dalam imaginasi mereka yaitu mereka akan membuat sebuah kalimat berdasarkan keingian masing-masing.Guru tidak akan memberikan contoh terlebih dahulu karena hal ini akan memberikan kesempatan kepada siswa untuk mengembangkan fikirannya dalam menyusun kalimat yang tepat menjadi sebuah paragraf yang runtun dan bermakna. Begitupun untuk siswa yang memiliki karakter dan kebutuhan yang berbeda, mereka akan menyusun kalimat dengan bantuan para pengajar untuk menulis dan mengungkapkan fikiran mereka.Selanjutnya, setelah semua siswa sudah menuliskan semua kaliat yang mereka pikirkan, guru akan menjelaskan lebih lanjut bagaimana penggunaan kongjungsi dengan tepat untuk menghubungkan kalimat dengan kalimat selanjutnya. Hal ini dimaksudkan agar siswa-siswa dapat mengerti dan paham lebih banyak tentang penggunaan kata sambung atau konjungsi pada sebuah kalimat yang akan membentuk sebuah paragraph yang memiliki makna.Siswa bekerja dalam kelompok untuk kembali membuat karangan yang lebih runtun dari sebelumnya, karena telah dijelaskan oleh guru bagaiman membuat karangan yang lebih baik. Dalam pembagian kelompok, semua siswa akan diacak supaya tidak ada perbedaan antara anak-anak dengan kebutuhan yang berbeda serta siswa lain pada umumnya. Hal ini sangat membantu siswa dengan kebutuhan yang berbeda karena teman-teman dalam satu kelompoknya bertanggung jawab untuk mengarahkan serta bekerja sama dengan baik.Setelah siswa menyelesaikan pekerjaan kelompoknya, guru akan 
memeriksa dan memberikan penilaian.Penilaian yang dimaksud adalah ketepatan penggunaan kongjungsi pada kalimat serta seberapa banyak siswa-siswa kelas 3 dapat menyusun kalimat menjadi paragraph dalam waktu yang telah diberikan. Penilaian yang diberikan tidak hanya pada aspek ketepatan penggunaan konjungsi saja, akan tetapi penilaian kelompok tentang bagaimana mereka bekerja sama dalam menyelesaikan tugas serta perkembangan siswa dengan kebutuhan yang berbeda dalam berpartisipasi didalam kelompoknya.Untuk mengurangi kejenuhan siswa serta memberikan pandangan terhadap siswa tentang bagaimana menyusun kalimat yang tepat, guru akan membacakan cerita pendek. Cerita pendek ini dilakukan karena siswa-siswa kelas 3 masih sangat antusias dalam mendengarkan sebuah cerita.Pada akhir pembelajaran, untuk mengetahui kemampuan siswa lebih jauh, pada post test diberikan worksheet dan mereka harus bekerja secara individual.Pengerjaan worksheet ini juga berlaku sama untuk siswa yang memiliki karakter dan kebutuhan yang khusus dan berbeda, hanya saja untuk mereka aka diberikan pendampingan yang lebih dalam menyusun setiap jawaban pada soal yang diberikan oleh guru. Hal ini dimaksudkan agar semua siswa tetap memperoleh input yang sama untuk menyelesaikan pertanyaan yang ada baik itu siswa dengan karakter serta kebutuhan yang khusus dan berbeda maupun siswa lain pada umumnya. Hanya saja, mereka akan diberikan soal dengan kata-kata yang lebih ringan dan mudah dipahami sehingga dalam pengerjaannya akan lebih mudah walaupun konten dan materinya tetap dalam lingkup yang sama. Menurut Eka Rizki \& Slameto, 2016 hasil belajar merupakan proses yang cukup kompleks. Artinya bahwa hasil belajar siswa dipengaruhi oleh faktor yang mendukung yaitu 1) faktor internal yang meliputi: faktor fisiologis dan faktor psikologis. 2) faktor eksternal meliputi: faktor lingkungan sosial dan non lingkungan social, peran siswa, peran guru serta model yang digunakan dalam pembelajaran.

Penelitian serupa pernah dilakukan oleh Erlina Ika Setyaningrum (2015) mahasiswa dari Universitas Negeri Yogjakarta dengan judul Keefektifan Metode Menulis Berantai dalam Kemampuan Menulis Cerita Pendek Siswa kelas X SMA Negeri 1 Galur, Kulon Progo, Yogjakarta. Hasil penelitian tersebut menunjukkan (1) terdapat perbedaan kemampuan siswa yang mengikuti pembelajaran menulis cerita pendek, antara siswa yang mengikuti pembelajaran menggunakan metode menulis berantai dengan siswa yang mengikuti pembelajaran tanpa menggunakan metode menulis berantai di SMA Negeri 1 Galur, hal ini ditunjukkan dengan nilai signifikansi nilai posttest pada uji independent t-test yang sebesar 0,015 lebih kecil dari 0,05; (2) efektivitas penggunaan metode menulis berantai lebih tinggi dari pada pembelajaran yang hanya menggunakan metode menulis konvensional dalam meningkatkan kemampuan menulis cerita siswa kelas X di SMA Negeri 1 Galur. Hal ini ditunjukkan dengan gain skor atau selisih rata-rata kelompok eksperimen sebesar 5,45 yang lebih tinggi dari ratarata kelompok kontrol sebesar 2,55.

Penelitian yang kedua dilakukan oleh Anastiya Susanti, mahasiswa Universitas Muhammadyah Surakarta dengan judul Peningkatan Keterampilan Menulis Karangan Narasi Melalui Penggunaan Strategi Estafet Writing Pada Mata Pelajaran Bahasa Indonesia Siswa Kelas V SDIT Luqman Al Hakim Kecamatan Sukodono Kabupaten Sragen Tahun Ajaran 2013/2014. Hasil dari penelitian ni adalah ketercapaian pada siklus I indikator tema/ gagasan mencapai prosentase $66,1 \%$, organisasi isi mencapai $57,2 \%$, tata bahasa $58,1 \%$, struktur dan kosakata $59,9 \%$ dan ejaan dan tata tulis $60,6 \%$. Sedangkan pada siklus II diperoleh prosentase pada indikator tema/ gagasan mencapai prosentase $79,5 \%$, organisasi isi mencapai $76,8 \%$, tata bahasa $75 \%$, struktur dan kosakata $76,8 \%$ dan ejaan dan tata tulis $78,6 \%$. Hal ini menunjukkan bahwa dengan penerapan strategi estafet writing dapat meningkatkan keterampilan menulis karangan narasi siswa kelas 5 SDIT Luqman Al Hakim pada mata pelajaran bahasa Indonesia tahun ajaran 2013/2014

Penelitian yang ketiga dilakukan oleh Ihda Puthri Wilda, mahasiswa dari Universitas Islam Indonesia yang melakukan penelitian dengan judul Pengaruh Penerapan Metode Menulis Berantai Terhadap Keterampilan Menulis Karangan Narasi Di Kelas IV SD Islam Annajah Petukangan Selatan Jakarta Selatan Tahun Ajaran 2013/2014. Penelitian ini memberikan hasil berupa nilai ratarata kelompok ekspreimen 56,93, setelah diberikan perlakuan dengan metode menulis berantai nilai rata-rata posttest kelas eksperimen mengalami peningkatan menjadi 74,93. Sedangkan hasil nilai ratarata pretest kelompok control 58,4 dan setelah diberi perlakuan dengan menggunakan metode konvensional hasil rata-rata posttest kelompok control menjadi 67,8. Dari hasil penghitungan nilai rata-rata kelas eksperimen mengalami peningkatan 18\%, sedangkan kelas control mengalami peningkatan $9,4 \%$. Kesimpula yang diambil adalah penggunaan metode menulis berantai yang 
dilakukan pada kelas eksperimen berpengaruh terhadap keterampilan menulis karangan siswa kelas IV SD Islam Annajah Jakarta Selatan tahun ajaran 2013/2014.

Penelitian-penelitian yang relevan diatas menunjukkan bahwa metode chain writing atau estafet writing atau menulis berantai berpengaruh terhadap keterampilan menulis siswa. Baik siswa pada tingkat dasar hingga tingkat menengah, oleh karena itu peneliti melakukan penelitian eksperimen menggunakan metode chain writing kepada siswa kelas 3 SD Tumbuh 3 Jogjakarta yang bertujuan melihat pengaruh dari metode tersebut terhadap hasil belajar menulis siswa kelas 3 baik siswa pada umumnya, maupun siswa yang memiliki kebutuhan khusus.

\section{METODE PENELITIAN}

Penelitan ini termasuk penelitian kuantitatif dimana data-data yang ada akan diolah dengan statistik dan akan di jelaskan menggunakan uraian deskriptif. Metode yang digunakan dalam penelitian ini adalah metode eksperimen one group pretest dan posttest, dimana hanya ada 1 group yang menjadi subjek penelitian tanpa ada kelas kontrol yang menjadi pembandingnya. Penelitian ini dilaksanakan pada bulan September hingga November 2016, bertempat di SD Tumbuh 3 Jogjakarta. Sasaran yang dituju dalam penelitian ini adalah siswa-siswa kelas 3 SD Tumbuh 3 Jogjakarta yang berjumlah 21 siswa, dengan pembagian 15 siswa laki-laki dan 6 siswa perempuan. Prosedur penelitian ada beberapa tahapan yaitu tahap persiapan, tahap pelaksanaan dan tahap penyusunan. Instrument yang digunakan dalam penelitian adalah lembar pengamatan observasi siswa dan guru. Adapun teknik pengumpulan data pada penelitian ini adalah observasi, wawancara, dokumentasi serta metode tes. Teknik analisis data menggunakan alat bantu SPSS 16 for windows dengan uji normalitas, uji validitas konstruksi dan uji homogenitas.

\section{HASIL PENELITIAN DAN PEMBAHASAN}

Penelitian dilakukan setiap hari kamis pada saat mata pelajaran bahasa Indonesia di kelas 3 yang terdiri dari 21 siswa dengan 5 siswa perempuan dan 13 siswa laki-laki. Perlakuan yang ada didalam kelas adalah guru dengan team teaching yang bertujuan memfasilitasi semua siswa, baik siswa pada umumnya maupun siswa dengan kebutuhan khusus yang ada didalam kelas. Pengujian dengan menggunakan SPSS juga dilakukan untuk mengetahui data-data yang dimiliki normal atau tidak serta homogen atau tidak. Berikut adalah tabel uji normalitas.

Berdasarkan tabel uji normalitas dengan SPSS 16 for windows diatas, hasilnya menunjukkan nilai signifikansi pretest sebesar $0,005<0,005$. Hal ini menunjukkan bahwa data distribusi tidak normal karena menunjukkan < 0,05, namun setelah diberikan perlakuan, nilai signifikansi posttest sebesar 0,099 >0,05. Hasil ini menerangkan bahawa setelah diberikan perlakuan, data distribusi normal karena > 0,05. Hasil yang menunjukkan angka 0.099 ini terlihat bahwa sebelum diberikan perlakuan dan setelah diberikan perlakuan, siswa dapat mengikutinya dengan baik. Meskipun masingmasing siswa memiliki hasil yang berbeda-beda dan tidak apat disama ratakan, tetapi terlihat ada hasil yang meningkat.

Berdasarkan hasil dari uji homogenitas diatas, nilai signifikansi menunjukkan $0,014<0.05$ menunjukkan tidak homogen, maka dilakukan uji ststistik non parametrik menggunakan uji Mann Whiteny sebagai berikut

Tabel Uji Non Paramatrik Menggunakan Mann
\begin{tabular}{|l|r|}
\hline & \multicolumn{1}{|c|}{ nilai } \\
\hline Mann-Whitney U & 55.000 \\
Wilcoxon W & 265.000 \\
Z & -3.934 \\
Asymp. Sig. (2-tailed) & .000 \\
Exact Sig. [2*(1-tailed & $.000=$ \\
\hline Siq.)]
\end{tabular}

Pemberian pretest dilakukan untuk mengetahui kemampuan awal masing-masing siswa, dan didapat distribusi interval nilai pre test adalah 
Pengaruh Metode Chain Writing Terhadap Hasil Belajar Menulis Siswa Kelas 3 Sekolah Dasar (Retno Fitriyanti, Eunice Widyanti Setyaningtias)

Tabel 1

Diastribusi Interval Nilai Pre Test Kelas 3

\begin{tabular}{lll}
\hline Interval skor & Frekuensi & Presentase \\
\hline $\mathbf{6 9 - 7 5}$ & 7 & $33,33 \%$ \\
\hline $\mathbf{7 6 - 8 2}$ & 14 & $66,67 \%$ \\
\hline $\mathbf{8 3 - 8 9}$ & 0 & 0 \\
\hline Total & 21 & $100 \%$ \\
\hline
\end{tabular}

Berdasarkan tabel data di atas, dapat dilihat bahwa nilai pretest siswa kelas 3 mayoritas terdapat pada interval nilai antara 76-82 yaitu sebanyak 14 siswa atau sebesar $66,67 \%$. Nilai pretest kemampuan menulis antara 69-75 sebanyak 7 siswa atau 33,33\%. Nilai pretest kemampuan menulis siwa antara nilai 83-89 sebanyak 0 siswa atau $0 \%$

Uji validitas konstruksi yang digunakan dalam penelitian ini, adalah instrumen non tes objektif (uraian) dari keterampilan menulis, sehingga validitas yang digunakan adalah validitas konstruksi (construct validity). Untuk menguji validitas konstruksi dapat menggunakan pendapat para ahli (judgment expert), dalam hal ini ahli yang diminta pendapatnya adaah guru mata pelajaran bahasa Indonesia kelas 3 SD Tumbuh 3 Jogjakarta.

Data yang didapat tidak hanya berasal dari nilai pretest saja, tetapi juga nilai posttest yang dilakukan setelah pemberian perlakuan metode chain writing. Didapat distribusi internal nilai posttest yaitu

Tabel 2

Distribusi Interval Nilai Posttest

\begin{tabular}{ccc}
\hline Interval skor & frekuensi & presentase \\
\hline $\mathbf{6 4 - 7 0}$ & 1 & 4,77 \\
\hline $\mathbf{7 1 - 7 7}$ & 3 & 14,29 \\
\hline $\mathbf{7 8 - 8 4}$ & 2 & 9,53 \\
\hline $\mathbf{8 5 - 9 1}$ & 5 & 23,80 \\
\hline $\mathbf{9 2 - 9 8}$ & 10 & 47,61 \\
\hline Total & 21 & $100 \%$ \\
\hline
\end{tabular}

Berdasarkan data dari tabel di atas, dapat dilihat bahwa mayoritas nilai posttest siswa kelas 3 berada antara 92-98 sebanyak 10 siswa atau 47,61\%. Nilai posttest kemampuan menulis antara 85-91 sebanyak 5 siswa atau 23,80\%. Nilai posttest kemampuan menulis antara 78-84 sebanyak 2 siswa atau 9,53\%. Nilai kemampuan menulis antara $71-77$ sebanyak 3 siswa atau $14,29 \%$. Serta nilai kemampuan menulis antara 64-70 sebanyak 1 orang siswa atau 4,77\%.

Berdasarkan hasil dari pretest dan posttest yang telah dilakukan pada siswa kelas 3 terlihat bahwa distribusi nilai mengalami perubahan dan setelah diberikan perlakuan, keterampilan menulis siwa kelas 3 terlihat lebih kreatif dibandingkan sebelum diberikan perlakuan berupa metode chain writing.

\section{SIMPULAN DAN SARAN}

SD Tumbuh 3 Jogjakarta adalah salah satu sekolah inklusi berstandar internasional multi usia. Dalam satu kelas terdapat beragam usia serta memiliki siswa-siswa dengan karakter dan kebutuhan yang khusus dan berbeda-beda. Hal ini juga sangat mempengaruhi dalam sistem pembelajaran yang ada, di dalam satu kelas terdapat dua guru yang bertugas sebagai guru kelas dan asisten guru ketika kegiatan belajar mengajar berlangsung. Hal lain yang tidak terlupakan adalah sistem penilaian yang dilakukan oleh guru untuk masing-masing siswa berbeda, tergantung pada kemampuan masingmasing siswa. Pemberian perlakukan saat kegiatan belajar mengajar pun sudah tentu berbeda. Siswa yang memiliki karakter dan kebutuhan yang khusus dan berbeda tidak dapat disama-ratakan dengan siswa lain. Keadaan tersebut yang membuat hasil dari nilai yang telah diteliti tidak sama. Keadaan subyek yang berbeda-beda membuat standar nilai tidak bisa sama. Hasil yang diperoleh dari penelitian ini adalah metode chain writing berpengaruh terhadap keterampilan menulis siswa kelas 3 . 
Pengaruh ini dapat dilihat pada hasil paragraf siswa yang lebih kreatif dalam menggunakan konjungsi atau kata hubung dalam menyusun kalimat menjadi sebuah paragraf yang lebih runtun dan bermakna.

Hasil belajar siswa setelah diberikan perlakuan berupa metode chain writing terlihat meningkat dengan signifikan. Siswa terlihat memiliki nilai yang lebih meningkat dan memiliki keterampilan menulis yang lebih kreatif. Pengaruh pada hasil akhir penelitian dapat dilihat melalui hasil pada tabel-tabel yang telah diolah menggunakan SPSS 16 for windows yaitu nilai saat belum diberikan perlakuan (pretest) menggunakan metode chain writing dengan nilai akhir setelah diberikan perlakukan (posttest) berbeda. Terlihat pula angka normalitas 0.099 dan homogenitas sebesar 0,014, angka-angka ini disebabkan subjek yang berbeda-beda dan tidak dapat disama ratakan.

\section{Saran}

Untuk peningkatan kualitas SD Tumbuh 3 menjadi sekolah inklusi yang lebih baik, semua elemen yang ada disekolah dapat mengoptimalkan seluruh sumber daya manusia agar sekolah dapat semakin meningkatkan mutunya dan menjadi sekolah inklusi andalan. Hal ini dimaksudkan untuk memberikan fasilitas serta pengajaran yang sangat maksimal untuk seluruh siswa-siswa tanpa terkecuali. Hal yang diperoleh dari penelitian tersebut adalah bagaimana cara mengkondisikan anakanak yang mempunyai berbagai macam sifat, kondisi serta kebutuhan masing-masing yang sangat berbeda antara satu anak dengan anak lainnya. (1) Siswa berkesulitan belajar ketika sedang mengikuti kegiatan belajar mengajar sudah tentu mengalami kendala dalam menerima setiap materi. Guru di dalam kelas harus memberikan perhatiannya kepada siswa learning disabilities. Perhatian ini dapat berupa pemberian tambahan pelajaran diluar jam belajar efektif, dengan tujuan siswa tersebut dapat mengejar ketertinggalannya dari teman-teman yang lain. Hal lain yang dapat dilakukan adalah pendampingan ketika kegiatan belajar mengajar berlangsung dengan mengontrol setiap hasil pekerjaan siswa agar dapat terlihat bagaimana perkembangannya dari waktu ke waktu. (2) Siswa tunagrahita lebih cenderung mengganggu teman-teman lainnya saat kegiatan belajar mengajar berlangsung. Selama penelitian ini dilaksanakan, untuk mengatur siswa dengan keadaan seperti ini harus melakukan perjanjian diawal pembelajaran untuk mengikuti kegiatan belajar mengajar hingga akhir. Hal ini memang tidak mudah untuk dikerjakan karena dia pasti mengajukan keberatan atas perjanjian tersebut. Siasat yang dapat dilakukan adalah dengan memberikan ijin bermain jika siswa tersebut telah berhasil menyelesaikan sebuah pekerjaan, reward atau hadiah yang diminta ketika kegiatan belajar mengajar sudah berakhir. (3) Siswa hyperactive dikelas ini termasuk siswa yang kreatif dalam bidang seni, tetapi ketika pelajaran yang lain dia kurang antusias. Siasat yang dapat dilakukan adalah ketika penjelasan berlangsung diusahakan siswa tersebut duduk sejenak mendengarkan setelah penjelasan selesai, siswa dapat melakukan pekerjaannya dengan berpindah tempat selama hal itu tidak mengganggu siswa-siswa yang lain.

Peneliti selanjutnya dapat lebih kreatif lagi dalam pemilihan metode yang mampu menggali seluruh potensi siswa dan bertujuan untuk membuat siswa-siswa yang memiliki kebutuhan yang khusus dan berbeda menjadi siswa unggulan dengan menunjukkan kemmapuan lain yang tidak dimiliki oleh siswa-siswa lain pada umunya dan tidak kalah dengan siswa-siswa lain pada umumnya. Semakin kreatif metode yang digunakan serta pemanfaatan media yang ada, membuat penelitian yang dilakukan menghasilkan sesuatu yang sarat makna dan sangat bermanfaat untuk khalayak umum.

Hal yang belum terlaksana dalam penelitian ini adalah melihat berbagai potensi lain yang dimiliki masing-masing siswa di dalam mata pelajaran yang lain. Harapannya, peneliti selanjutnya dapat lebih dalam untuk menggali potensi siswa baik itu siswa dengan kebutuhan yang khusus dan berbeda maupun siswa lain pada umumnya.

\section{DAFTAR PUSTAKA}

Abdurrahman, M. 2012. Anak Berkesulitan Belajar Teori, Diagnosis, dan Remediasinya. Jakarta: PT. Rineka Cipta.

Al-Tabany, T. I. 2014. Mendesain Model Pembelajaran Inovatif, Progresif, dan Kontekstual. Jakarta: Prenadamedia Group.

Bianco, A. 2002. One Minute Discipline: Classroom Management Strategies That Work. United State of America: John Wiley\&Sons, Inc. 
Pengaruh Metode Chain Writing Terhadap Hasil Belajar Menulis Siswa Kelas 3 Sekolah Dasar (Retno Fitriyanti, Eunice Widyanti Setyaningtias)

Brower, F. 2007. 100 Ide Membimbing Anak Autis. Jakarta: Penerbit Erlangga.

Delphie, B. 2006. Pembelajaran Anak Tunagrahita Suatu Pengantar Pendidikan Inklusi. Bandung: PT. Refika Aditama.

Hornby, G. 2015. Inclusive Special Education: Development of a new theory for the education of children with special need and disabilities. British Journal of Special Education, 235-255.

Latham, G. K. 2010. 100 Ide Membimbing Anak ADHD. Jakarta: Penerbit Erlangga.

Mackenzie, N., \& Veresov, N. 2013. How Drawing can Support Writing Acquisition: Text Costraction in Early Writing from a Vygotskian Perpective. Australasian Journal of Early Childhood, 22-29.

Meglemre, J. 2016. Fair does not mean equal: Creating an Inclusive Environment For Students With Disabilities. Leadership, 36-41.

Peterson, S. S., Mclntyre, L. J., \& Forsyth, D. 2016. Supporting Young Children's Oral Language and Writing Development: Teachers' and Early Childhood Educators' Goals and Practices. Australasian Journal of Early Childhood, 11-19.

Sabarti Akhadiah, M. G. 1988. Pembinaan Kemampuan Menulis Bahasa Indonesia. Jakarta: Penerbit Erlangga.

Setyaningrum. Ika Erlina, 2015. Keefektifan Metode Menulis Berantai Dalam Kemampuan Menulis Cerita Pendek Siswa Kelas X SMA Negeri 1 Galur Kulon Progo Yogjakarta. Skripsi. Universitas Negeri Yogjakarta. Yogjakarta.

Shelley Stagg Peterson, L. J. 2016. Supporting young children's oral language and writing development: Teachers' and ealy chldhood educators goal and practices. Australasian Journal of Early Childhood, 10-19.

Widayanti, E. R., \& Slameto, S. 2016. Pengaruh Penerapan Metode Teams Games Tournament Berbantuan Permainan Dadu Terhadap Hasil Belajar IPA. Scholaria: Jurnal Pendidikan dan Kebudayaan, 6(3), 182-195.

Smith, J. D. 2006. Inklusi Sekolah Ramah untuk Semua. Bandung: Penerbit Nuansa.

Susanti, A. 2014. Peningkatan Keterampilan Menulis Karangan Narasi Melalui Penggunaan Strategi Estafet Writing Pada Mata Pelajaran Bahasa Indonesia Siswa Kelas V SDIT Luqman Al Hakim Kecamatan Sukodono Kabupaten Sragen Tahun Ajaran 2013/2014. Doctoral dissertation, Universitas Muhammadiyah Surakarta.

Tritjahjo Soesilo, M. 2015. Penelitian Eksperimen. Salatiga: Griya Media.

Wilda. Puthri Ihda, 2014. Pengaruh Metode Menulis Berantai Terhadap Keterampilan Menulis Karangan Narasi di Kelas IV SD islam Annajah Petukangan Selatan Jakarta Selatan Tahun Ajaran 2013/2014. Skripsi. Universitas Islam Negeri Syarif Hidayatullah. Jakarta.

Wulansari. Tri Retno Agnes, 2016. Efektifitas Penggunaan Model Pembelajaran Kooperatif Tipe Gallery Walk dengan Jigsaw Terhadap Hasil Belajar IPS Kelas V Sd Pangudi Luhur Ambarawa Semester II Tahun Pelajaran 2015/2016. Skripsi. Universitas Kristen Satya Wacana. Salatiga. 